\author{
$\mathrm{J}_{\mathrm{AN}} \mathrm{STOKSIK}^{1}$
}

\title{
Formy wspierania rozwoju gospodarstw rolnych w Programie Rozwoju Obszarów Wiejskich na lata 2014-2020
}

W dniu 12 grudnia 2014 r. Komisja Europejska (dalej KE) zatwierdziła przesłany przez Polskę Program Rozwoju Obszarów Wiejskich na lata 2014-2020. ${ }^{2}$ Program ten, będący podstawowym narzędziem realizacji polityki rozwoju obszarów wiejskich, wskazał w pkt 5 na jego cele przekrojowe, szczegółowe oraz priorytety. Pozostają one w zgodności z treścią art. 4 i 5 rozporządzenia Parlamentu Europejskiego i Rady (UE) nr 1305/2013 z dnia 17 grudnia 2013 r. w sprawie wspierania rozwoju obszarów wiejskich przez Europejski Fundusz Rolny na rzecz Rozwoju Obszarów Wiejskich (EFRROW) i uchylające rozporządzenie Rady (WE) nr $1698 / 2006 .^{3}$

Polityka rozwoju gospodarstw rolnych nieprzerwanie stanowi ważny element szerszej przedmiotowo polityki rozwoju obszarów wiejskich. Na użytek rozważań zawartych w niniejszej pracy, zasadnym będzie wskazać, w syntetycznym zarysie, na najważniejsze strategiczne i prawne dokumenty UE, a także na pozostające w związku z nimi dokumenty krajowe. Jedne i drugie wyznaczyły w istocie najważniejsze kierunki i ramy prawne polityki rozwoju obszarów wiejskich. Na poziomie UE znaczenie podstawowe należy przypisać dwóm strategicznym dokumentom Komisji UE z 2010 r. Pierwszy z nich to: Wspólna polityka rolna do 2020 r.: sprostać wymaganiom przyszłości związanym z żywnością, zasobami naturalnymi i aspektami terytorialnymi. ${ }^{4}$ Drugi z kolei dokument to: Europa 2020. Strategia na rzecz inteligentnego i zrównoważonego rozwoju sprzyjającemu włączeniu społecznemu. ${ }^{5}$ Dokumenty te stanowiły podstawę do opracowania całego pakietu projektów unijnych aktów normatywnych, dotyczących wspierania rozwoju obszarów wiejskich.

$1 \quad$ Uniwersytet Kardynała Stefana Wyszyńskiego w Warszawie.

2 Decyzją wykonawczą nr 2014 P06 RDN-P001. Tekst tego Programu dostępny jest na stronach internetowych Ministerstwa Rolnictwa i Rozwoju Wsi, w wersji pełnej oraz skróconej, www.min.rol.gov.pl. W dalszej części pracy Program ten przywoływany będzie jako PROW 2014-2020 lub Program.

3 Dz.Urz. UE, L347/487 z dnia 20 grudnia 2013 r.; w dalszej części pracy rozporządzenie to przywoływane będzie jako rozporządzenie EFRROW lub rozporządzenie 1305/2013.

4 COM/2010/672 wersja ostateczna.

5 COM/2010/2020/ wersja ostateczna, Bruksela 3 marca 2010 r. 
Duże znaczenie dla rozwoju rolnictwa i terenów wiejskich w Polsce miały ustalenia szczytu UE z marca 2013 r., na którym zdecydowano, że nasz kraj otrzymał najwyższe wsparcie ze wszystkich funduszy unijnych. Na rozwój naszych obszarów wiejskich, w tym na rolnictwo, przewidziano wsparcie, łącznie w wysokości $32 \mathrm{mld}$ euro. ${ }^{6} \mathrm{Na}$ sfinansowanie działań PROW 2014-2020 przewidziano natomiast kwotę ponad 13,5 mld euro. ${ }^{7}$

Z krajowych dokumentów o charakterze strategicznym, poprzedzających przyjęcie PROW 2014-2020 podstawowe znaczenie posiada Strategia zrównoważonego rozwoju wsi, rolnictwa i rybactwa na lata 2012-2020, przyjęta uchwałą nr 163 Rady Ministrów z dnia 25 kwietnia 2012 r. ${ }^{8}$ Celem głównym tej Strategii ma być poprawa jakości życia na terenach wiejskich oraz efektywne wykorzystanie ich zasobów i potencjałów, w tym rolnictwa i rybactwa dla zrównoważonego rozwoju kraju. Cele szczegółowe będą natomiast przywoływane w toku dalszych wywodów.

Głównym narzędziem przywołanej wyżej Strategii, realizującym jej cel ogólny oraz cele szczegółowe, jest PROW 2014-2020. Rozporządzenie PROW 2014-2020 w art. 4 wyznaczyło trzy cele rozwoju obszarów wiejskich o charakterze przekrojowym. Są nimi:

1) wspieranie konkurencyjności rolnictwa,

2) zapewnienie zrównoważonego zarządzania zasobami naturalnymi oraz działania w dziedzinie klimatu,

3) osiągnięcie zrównoważonego rozwoju terytorialnego wiejskich gospodarek i społeczności, w tym utrzymanie miejsc pracy.

Te trzy, o przekrojowym charakterze, cele realizowane będą przy zachowaniu sześciu, określonych w art. 5 analizowanego rozporządzenia, priorytetów UE. Są nimi w kolejności:

1. Ułatwianie transferu wiedzy i innowacji w rolnictwie i leśnictwie oraz na obszarach wiejskich.

2. Zwiększanie rentowności gospodarstw rolnych i konkurencyjności wszystkich rodzajów rolnictwa we wszystkich regionach oraz promowanie innowacyjnych technologii w gospodarstwach rolnych i zrównoważonego zarządzania lasami.

3. Wspieranie organizacji łańcucha żywnościowego, w tym przetwarzania i wprowadzania do obrotu produktów rolnych, dobrostanu zwierząt oraz zarządzania ryzykiem $\mathrm{w}$ rolnictwie. 
Formy wspierania rozwoju gospodarstw rolnych w Programie Rozwoju Obszarów...

4. Odtwarzanie, ochrona i wzbogacanie ekosystemów związanych z rolnictwem i leśnictwem.

5. Promowanie efektywnego gospodarowania zasobami i wspieranie przechodzenia w sektorach rolnym, spożywczym i leśnym na gospodarkę niskoemisyjną i odporną na zmianę klimatu.

6. Promowanie włączenia społecznego, zmniejszanie ubóstwa oraz rozwoju gospodarczego na obszarach wiejskich.

Szczególnie istotnym zagadnieniem rozwoju obszarów wiejskich pozostaje nadal nieprzerwanie budowa konkurencyjności naszego rolnictwa. Służyć temu powinny programy pomocowe, które poprzez należycie zaprogramowane działania powinny prowadzić do poprawy konkurencyjności polskich gospodarstw rolnych. Skuteczność ferowanej pomocy zależeć będzie nie tylko od jej zakresu, ale także od odpowiedniego doboru działań, a w ich ramach, form wsparcia i dostępności do nich, poprzez trafnie dobrane kryteria dostępu. Doboru takiego już dokonano w oparciu o rzetelną diagnozę potrzeb wsi, rolnictwa, przetwórstwa rolno-spożywczego oraz aktualnych wyzwań stojących przed rolnictwem, branżą przetwórczą i mieszkańcami wsi.

W obecnej perspektywie finansowej, podobnie zresztą jak w poprzedniej, diagnozy potrzeb dokonano, stosownie do treści art. 8, ust. 1, lit b rozporządzenia EFRROW, poprzez analizę SWOT. ${ }^{9}$ Przywołajmy zatem najważniejsze wyniki tej analizy w zakresie słabych i mocnych stron, następnie szans i zagrożeń w obszarze objętym PROW 2014-2020, by z kolei na bazie tak uzyskanych informacji, wskazać na najważniejsze i najpilniejsze potrzeby dla rozwoju rolnictwa oraz obszarów wiejskich.

Komentowana tutaj analiza SWOT wykazała, że mocnymi stronami będą: duże zasoby niewykorzystanych bądź nienależycie wykorzystanych gruntów rolnych, stała, choć nadal powolna, tendencja do powiększania się średniej powierzchni gospodarstw rolnych, wielobranżowość i regionalna specjalizacja poszczególnych branż produkcji rolnej, korzystne warunki dla rozwoju rolnictwa ekologicznego wynikające z niewielkiego zanieczyszczenia gleb środkami chemicznymi, wysokiej różnorodności biologicznej terenów wiejskich, dużych zasobów ludzkich, pozwalających na rozwój na tych terenach także działalności pozarolniczej.

Słabe z kolei strony to: ciągle niska rentowność sektora rolnego, niedofinansowanie gospodarstw rolnych, niekorzystna struktura agrarna $\mathrm{z}$ dominacją gospow danej sprawie na cztery grupy, tekst jedn.: S (Strenghts) - ukazującej mocne strony analizowanego obiektu; W (Weaknesses) - ukazującej słabe strony analizowanego obiektu; O (Opportunities) - ukazującej szanse korzystnej zmiany analizowanego obiektu; T (Treats) - ukazującej zagrożenia i niebezpieczeństwa zmian dla analizowanego obiektu). 
darstw małych, duży udział gleb słabych i problemy z bilansem wody, słabo rozwinięta infrastruktura techniczna i społeczna na obszarach wiejskich, przy nadmiarze słabo wykształconej siły roboczej i dużym bezrobociu, niska mobilność zawodowa mieszkańców wsi, słaba sieć usług na terenach wiejskich.

Istotne znaczenie dla doboru działań i form wsparcia rozwoju gospodarstw rolnych miało również zidentyfikowanie szans oraz zagrożeń w obszarze objętym programem pomocowym. Szans tych należy upatrywać m.in.: w otwartym dostępie do unijnego rynku i rynków trzecich, wzroście popytu wewnętrznego wynikającego z utrzymującego się wzrostu gospodarczego, wzroście popytu na produkty wyżej przetworzone i niszowe, młodej sile roboczej na rynku pracy oraz w rolnictwie, wzroście zainteresowania terenami wiejskimi jako miejscu zamieszkania i wypoczynku.

Wreszcie, do najważniejszych zagrożeń zaliczono: wzrost ubóstwa i wykluczenia społecznego na terenach wiejskich oraz ograniczone możliwości dywersyfikacji zatrudnienia osób odchodzących z rolnictwa, wynikające z powolnego wzrostu gospodarczego, rosnącą konkurencję zagranicznego sektora rolno-spożywczego, co może prowadzić do utraty własnej, stabilnej bazy surowcowej w niektórych sektorach rynku (w Polsce ma to miejsce w chowie świń), istniejące bariery prawne i fiskalne, które ograniczają rozwój handlu i małego przetwórstwa oraz hamują rozwój alternatywnych kanałów sprzedaży dla małych gospodarstw rolnych.

Powyższe wyniki analizy SWOT uzasadniły więc ustalenie, na użytek opracowywanego PROW 2014-2020, dwanaście potrzeb, które zdeterminowały liczbę oraz treść działań i poddziałań tego Programu. Warto te potrzeby wskazać w całości. Oto one:

1. Zwiększenie liczby konkurencyjnych gospodarstw rolnych.

2. Reorientacja małych gospodarstw w kierunku rolniczym lub pozarolniczym.

3. Zapewnienie trwałości rolnictwa w obliczu zmian klimatu i naturalnych ograniczeń oraz ochrony i poprawy stanu wód gruntowych.

4. Poprawa zbytu produktów rolnych i wzmocnienie pozycji rolników w łańcuchu żywnościowym.

5. Poprawa jakości produktów rolnych i żywnościowych.

6. Odtwarzanie i zachowanie różnorodności biologicznej, także na obszarach NATURA 2000 oraz na obszarach o utrudnieniach naturalnych.

7. Promowanie zrównoważonych metod gospodarowania oraz rolnictwa zrównoważonego i ekologicznego.

8. Zachowanie zasobów genetycznych roślin uprawnych oraz zwierząt gospodarskich. 
9. Tworzenie możliwości zatrudnienia poza rolnictwem, bez zmiany miejsca zamieszkania.

10. Rozwój infrastruktury technicznej i społecznej na obszarach wiejskich.

11. Aktywizacja mieszkańców obszarów wiejskich i wykorzystanie potencjałów endogenicznych na rzecz rozwoju lokalnego.

12. Wzrost innowacyjności i unowocześnienia sektora rolno-spożywczego oraz podniesienie poziomu wiedzy producentów rolnych. Promowanie, zwłaszcza zrównoważonych, metod gospodarowania w rolnictwie.

Tak wybrane potrzeby wymagały jeszcze dodatkowego uzasadnienia wokół celów, priorytetów, celów szczegółowych, celów końcowych wskazanych w rozporządzeniu EFRROW. Dla każdego celu szczegółowego dokonano z kolei połączenia i uzasadnienia działań na rzecz rozwoju rolnictwa i obszarów wiejskich, opierając się na dowodach pochodzących z analizy SWOT oraz uzasadnieniu hierarchii ważności potrzeb. Przy takich uwarunkowaniach, wśród których ważne znaczenie ma ograniczona wielkość pozostających do dyspozycji środków finansowych, przyjęty program pomocowy musiał ograniczyć wybór możliwej liczby działań oraz skoncentrować w ich ramach w miarę największą liczbę problemów, które poprzez te działania powinny być rozwiązywane.

O trwałości gospodarstw rolnych w dłuższej perspektywie czasowej decydować będzie ich zdolność do konkurowania $\mathrm{z}$ innymi gospodarstwami na jednolitym unijnym rynku oraz rynkach światowych, na które coraz mocniej wchodzimy. Gospodarstwa konkurencyjne z reguły są większe, dużo inwestują, są bardziej podatne na innowacje, częściej podejmują grupową działalność, umacniając przez to swą pozycję rynkową, czy wreszcie łatwiej podejmują przedsięwzięcia na rzecz środowiska naturalnego. ${ }^{10}$

Gospodarstwa rolne zawsze były postrzegane jako najważniejszy motor rozwoju obszarów wiejskich. Przybliżona wyżej analiza SWOT, jak też badania wielu ekonomistów, formułują zgodny pogląd, że polskie gospodarstwa rolne nie są wystarczająco konkurencyjne, aby sprostać zagranicznej konkurencji. Dlatego też ważnym celem naszej krajowej polityki rolnej powinno być podejmowanie wszelkich, wielotorowych działań na rzecz ustawicznego wzmacniania tej konkurencyjności. ${ }^{11}$

10 Konkurencyjności polskich gospodarstw rolnych poświęcono w ostatnim czasie sporo miejsca w literaturze ekonomicznej. O pozytywnej roli gospodarstw konkurencyjnych w ramach globalizacji gospodarki światowej zob. zwłaszcza: W Józwiak, Efektywność, koszty produkcji i konkurencyjność polskich gospodarstw rolnych obecnie i w perspektywie średnio- oraz długoterminowej W Józwiaka (red.), Warszawa 2014, s. 7 i nast.

11 Wiele wniosków postulujących potrzebę działań w tym kierunku zawiera zbiorowy raport naukowy pod red. R. Grochowskiej, R. Grochowska (red.), Kierunki rozwoju rolnictwa i polityk rolnych - wyzwania przyszłości. Synteza, Warszawa 2014. Z myślą o zainteresowanych tą problematyką warto dodać, że celem tej pracy jest ocena zmian zachodzących w strategiach oraz politykach sektora rolnego na świecie i w UE, a także nakreślenie kierunków ich rozwoju w przyszłości i wynikających z tego implikacji dla sektora żywnościowego w Polsce. Zob. też uogólniające wnioski końcowe tego raportu, autorstwa R. Grochowskiej, s. 114 i nast. 
Działań/poddziałań PROW 2014-2020, skierowanych bezpośrednio na wspieranie w różnych formach rozwoju gospodarstw rolnych, jest w mojej ocenie siedem. Oto one:

1. Premie dla młodych rolników;

2. Restrukturyzacja małych gospodarstw rolnych;

3. Płatność dla rolników przekazujących małe gospodarstwa rolne;

4. Modernizacja gospodarstw rolnych;

5. Inwestycje w gospodarstwach rolnych położonych na obszarach Natura 2000;

6. Inwestycje w gospodarstwach rolnych położonych na obszarach OSN;

7. Tworzenie grup i organizacji producentów.

W PROW 2014-2020 najwyższą kwotę przewidziano na wspieranie przedsięwzięć przewidzianych w ramach poddziałania „Modernizacja gospodarstw rolnych” (2,4 mld euro). Od tego też działania rozpoczniemy analizę działań skierowanych w głównej mierze, na rozwój gospodarstw rolnych. W porównaniu z analogicznym działaniem w PROW 2007-2013, na którego wsparcie przewidziano 4,4 mld euro, obecnie jest to kwota zdecydowanie niższa, zmniejszona kosztem innych działań.

Analizowane tutaj działanie ma realizować cel szczegółowy, wyartykułowany w pkt 2 a art. 5 rozporządzenia 1305/2013, jakim jest poprawa wyników gospodarczych wszystkich gospodarstw oraz ułatwianie ich restrukturyzacji i modernizacji, szczególnie z myślą o zwiększaniu ich uczestnictwa w rynku i zorientowania na rynek, a także zróżnicowania produkcji rolnej. Wszystkie realizowane w ramach tego poddziałania operacje mają prowadzić do poprawy konkurencyjności i zwiększenia rentowności gospodarstw w wyniku podjętej przez nie restrukturyzacji.

W związku z wykazanymi w przeprowadzonej analizie SWOT zagrożeniami, szczególny nacisk zdecydowano położyć na rozwój produkcji zwierzęcej, nie zamykając wsparcia dla pozostałych kierunków produkcji rolnej. W związku z powyższym wsparcie przewidziane Programem skierowane będzie w największym zakresie na następujące obszary:

- rozwój produkcji prosiąt,

- rozwój produkcji mleka krowiego,

- racjonalizację technologii produkcji, wprowadzanie innowacji, zmianę profilu produkcji, zwiększanie skali produkcji, poprawę jakości produkcji oraz zwiększanie wartości dodanej produktu.

Jednym ze sprawdzonych sposobów osiągania wytyczonych celów, poprzez wdrażanie określonych form pomocy, są odpowiednio sprecyzowane kryteria dostę- 
pu do wnioskowanego wsparcia. ${ }^{12} \mathrm{~W}$ odniesieniu do analizowanego tutaj poddziałania wsparcie powinno prowadzić do poprawy ogólnych wyników ekonomicznych gospodarstwa rolnego poprzez poprawę jego konkurencyjności i rentowności. Analizowany program zakłada, że wzrost wartości dodanej brutto w gospodarstwach powinien następować $\mathrm{w}$ wyniku racjonalizacji technologii produkcji, wprowadzania innowacji, zmiany profilu lub skali produkcji, wprowadzania innowacji, poprawy jakości produkcji, zwiększenia wartości dodanej produktu, ${ }^{13}$ co najmniej o $10 \%$ w odniesieniu do roku bazowego w okresie 5 lat, liczonego od dnia przyznania pomocy.

Nabory wniosków o przyznanie pomocy będą ogłaszane w ramach wskazanych wyżej obszarów uznanych jako szczególnie zagrożone. Zakłada się, że każda z przyjętych do finansowania operacji będzie musiała obowiązkowo przyczyniać się do realizacji przywołanego już wyżej celu szczegółowego, określonego w pkt 2a art 5 rozporządzenia 1305/2013.

Przyjęty do finansowania projekt powinien dodatkowo przyczyniać się także do realizacji celu wskazanego w pkt 2 b art. 5 analizowanego rozporządzenia, jakim jest ułatwianie wejścia rolników posiadających odpowiednie umiejętności do sektora rolnictwa, a w szczególności do wymiany pokoleń. Alternatywnie w rachubę może wchodzić jeden z celów szczegółowych wskazanych w pkt 5 art. 5 rozporządzenia EFRROW, generalnie prowadzących do efektywnego gospodarowania zasobami i przechodzenia na gospodarkę niskoemisyjną oraz odporną na zmianę klimatu w sektorach rolnym, spożywczym i leśnym.

Beneficjentami analizowanej tutaj formy wsparcia, jaką jest refundacja części kosztów kwalifikowanych, mogą być rolnicy prowadzący działalność rolniczą lub grupa rolników prowadzących tę działalność na terytorium Rzeczypospolitej Polskiej. Rolnik ubiegający się o wsparcie powinien posiadać gospodarstwo o powierzchni co najmniej 1 ha lub nieruchomość, na której prowadzi produkcję w zakresie działów specjalnych produkcji rolnej (w tym przypadku może być mniejsza od 1 ha) oraz kierować tym gospodarstwem.

Kolejnym kryterium wyboru beneficjenta jest wielkość ekonomiczna gospodarstwa $^{14}$ uprawnionego do otrzymania pomocy. Powinna ona stanowić równowartość pu stosowane było już w latach 90 . ub. stulecia w ramach realizowanych wtedy różnych form pomocy finansowej, skierowanej przykładowo na wspieranie przedsięwzięć inwestycyjnych, których celem było dostosowywanie naszych gospodarstw rolnych do standardów gospodarstw unijnych.

13 Wzrost wartości dodanej brutto w gospodarstwie (GVA) - wskaźnik ekonomiczny ustalany już na potrzeby PROW 2007-2013. Wzrost ten ustalany jest w oparciu o dane z gospodarstwa sprzed złożenia wniosku o pomoc i po zrealizowaniu przedsięwzięcia.

14 Wskaźnik ekonomiczny wykorzystywany na potrzeby określania kryteriów dostępu do niektórych działań PROW 2014-2020. Wielkość ta wyliczana jest w oparciu o współczynnik standardowej produkcji opracowywany w Instytucie Ekonomiki Rolnictwa i Gospodarki Żywnościowej. Poglądowy kalkulator służący wyliczaniu tej wielko- 
co najmniej 10 tys. euro i nie być większą niż 200 tys. euro. Od tego wymogu Program przewidział złagodzone kryteria w odniesieniu do młodych rolników podejmujących się produkcji mleka krowiego.

W Programie przyjęto również łagodniejsze kryteria dostępu dla rolników tworzących grupę, w której funkcjonowałoby gospodarstwo nie posiadające wymaganej wielkości ekonomicznej. W tym przypadku wsparcie będzie możliwe, gdy w wyniku zrealizowania przedsięwzięcia gospodarstwo osiągnie wymagalną wielkość ekonomiczną. Jednakże suma wielkości ekonomicznej gospodarstw tworzących grupę producencką wynosić będzie minimum 15 tys. euro. Poczyniono przy tym zastrzeżenie, że żadne z gospodarstw tworzących grupę nie może przekraczać maksymalnej wielkości ekonomicznej oraz powierzchni gospodarstwa, które przekraczałoby 300 ha. W tym miejscu należy zauważyć, że ten powierzchniowy wymóg dotyczy wszystkich gospodarstw ubiegających się o każde wsparcie przewidziane Programem. Innym ważnym wymogiem jest dokonanie oceny poprzedzającej rozpoczęcie inwestycji w zakresie jej oddziaływania na środowisko, w każdym przypadku gdy inwestycja może mieć na nie negatywny wpływ (art. 45 ust. 1 rozporządzenia EFRROW).

Program wymaga również, aby poprzez realizację inwestycji wartość dodana brutto w gospodarstwie wzrosła o co najmniej $10 \%$ w odniesieniu do roku bazowego, w okresie 5 lat liczonego od dnia przyznania pomocy. Od tego dnia beneficjent zobowiązany jest do prowadzenia w gospodarstwie uproszczonej rachunkowości. ${ }^{15}$ Prognozuje się, że chętnych do analizowanej tutaj formy wsparcia będzie dużo, co sprawi, że środków planowanych na to wsparcie nie wystarczy, aby zaspokoić wszystkich wnioskujących o pomoc. Dlatego też Program przewidział preferencje dla niektórych operacji, takich jak: budowa i modernizacja budynków inwentarskich, inwestycje wpływające na zwiększenie uczestnictwa w rynku, zróżnicowanie produkcji rolnej, produkcji ekologicznej, czy przedsięwzięcia wpływające na realizację celów przekrojowych (np. efektywne korzystanie z zasobów wodnych, energii pochodzącej z odnawialnych źródeł, redukcja emisji gazów cieplarnianych). Sprawiedliwy podział środków ma zabezpieczać poddanie wniosków ocenie punktowej, według zasad określonych w przepisach wykonawczych. Suma uzyskanych punktów będzie decydowała o kolejności przysługiwania pomocy. Rozwiązania te ocenić należy jako w pełni słuszne.

ści udostępniony jest na stronie internetowej - http.//ksow.pl/news/entry/5010-prow-2014-2020-obliczanie-wielkości-ekonomicz.html).

15 Prowadzenie ksiąg rachunkowych metodą uproszczoną wymagane jest w przypadku niektórych podmiotów korzystających z pomocy publicznej. Zasady ich prowadzenia reguluje rozporządzenie Ministra Finansów z dnia 15 listopada 2001 r. w sprawie szczegółowych zasad rachunkowości dla jednostek niebędących spółkami handlowymi, nieprowadzących działalności gospodarczej (Dz.U. Nr 137, poz. 1539 ze zm.). 
W Programie przewidziano wreszcie preferencje w odniesieniu także do kwot i stawek wsparcia. Ustanowiono je dla młodych rolników i inwestycji zbiorowych (objęcie wsparciem 60\% kosztów kwalifikowalnych, przy 50\% w przypadku pozostałych operacji). Minimalny poziom wsparcia powinien wynosić nie mniej niż $30 \%$ kosztów kwalifikowalnych. Od strony kwotowej najwyższe wsparcie przewidziano w przypadku operacji, których celem jest rozwój produkcji prosiąt (900 tys. zł). W przypadku realizacji pozostałych celów, wsparcie nie może przekroczyć 500 tys. zł.

Analizując wsparcie przewidziane powyższym poddziałaniem, warto jeszcze dodać, że Program przewidział możliwość weryfikacji i kontroli działań lub rodzajów operacji, wskazując na ryzyka związane z realizacją zadań. Dotyczy to zwłaszcza zagrożenia tzw. efektem deadweight. ${ }^{16}$

Dokonując ogólnej, wstępnej oceny analizowanego tutaj poddziałania należy już na wstępie stwierdzić, że wyartykułowane cele tego działania: ogólne, szczegółowe oraz przekrojowe pozostają w wyraźnym związku ze wskazanymi w Programie potrzebami, które Program będzie zaspokajał, niestety nie w pełnym już zakresie. Należy tutaj zaznaczyć, że potrzeby te zdiagnozowane wokół unijnych priorytetów wyartykułowanych w rozporządzeniu EFRROW będą realizowane głównie poprzez instrumenty dostępne w Programie, a niektóre w ramach nowego systemu płatności bezpośrednich oraz polityki krajowej.

W analizowanym tutaj poddziałaniu słusznie postawiono głównie na zwiększenie liczby konkurencyjnych gospodarstw rolnych, zwłaszcza w zagrożonych kierunkach produkcji rolniczej (chów trzody chlewnej, produkcja mleka, chów bydła mlecznego). Postawiono też słusznie na przedsięwzięcia prowadzące do: racjonalizacji technologii produkcji, innowacji w produkcji rolniczej, zmiany profilu produkcji, zwiększaniu skali produkcji, poprawy jakości produkcji i zwiększeniu wartości dodanej produkcji. Założenie powyższe uznać należy jako w pełni zasadne, jeśli zważyć, że o kondycji rolnictwa, liczącego się w całym świecie, decydować będzie duża liczba większych, a przede wszystkim, konkurencyjnych gospodarstw rolnych.

Wśród działań i poddziałań PROW 2014-2020 poddziałanie „Restrukturyzacja małych gospodarstw" zajmuje kolejne miejsce pod względem wielkości zaangażowania środków z budżetu UE na jego wdrażanie (882 980666 euro). Wśród ok. 1,5 mln polskich gospodarstw rolnych prowadzących działalność rolniczą dominują gospodarstwa do 5 ha (55\%) i o standardowej produkcji do 4 tys. euro (51\%). Nie oznacza to jeszcze, że niski wkład małych gospodarstw rolnych w produkcję rolniczą wykluczał będzie pełnienie przez nie istotnych funkcji w wymiarze społeczze środków publicznych, a więc także unijnych, które i bez tej pomocy zostałyby zrealizowane bez wsparcia zewnętrznego. 
nym, ekonomicznym czy środowiskowym. ${ }^{17}$ Powyższe względy przemawiają zatem za podtrzymaniem istnienia i żywotności także małych gospodarstw rolnych, zwłaszcza w dziedzinach nie wymagających większych zasobów gruntów do produkcji rolniczej. Powyższe względy uzasadniły również zasadniczy cel wspierania tych gospodarstw, którym jest stymulowanie takich zmian, aby te przyczyniały się do poprawy ich konkurencyjności i rentowności poprzez wzrost wielkości ekonomicznej, w szczególności w wyniku zmiany profilu produkcji rolnej.

Wsparcie przewidziane w ramach tego poddziałania będzie realizować również inne cele wytyczone małym gospodarstwom w PROW 2014-2020. Przesądziło to o treści kryteriów wyboru projektów, które powinny preferować w szczególności: rodzaj planowanej produkcji (np. produkcję ekologiczną), wielkość ekonomiczną gospodarstwa, wpływ na realizację celów przekrojowych, kompleksowość biznesplanu, przetwarzanie produktów rolnych wytwarzanych w gospodarstwie, udział w zorganizowanych formach współpracy producentów rolnych oraz kwalifikacje zawodowe rolnika.

Analizując dalej tę formę wsparcia wypada także zwrócić uwagę na kryterium wymaganej wielkości ekonomicznej gospodarstwa beneficjenta. Powinna się ona kształtować poniżej 10 tys. euro, a w wyniku realizacji przedsięwzięcia przewidzianego biznesplanem, powinien nastąpić wzrost wielkości ekonomicznej gospodarstwa do poziomu co najmniej 10 tys. euro, przy czym wzrost ten musi wynieść co najmniej $20 \%$ wartości wyjściowej. Wydaje się, że jest to wymóg trudny do spełnienia, zwłaszcza dla gospodarstw o niskiej wielkości ekonomicznej, dla których osiągnięcie poziomu wielkości ekonomicznej o wysokości co najmniej 10 tys. euro będzie bardzo trudne. Dotyczy to zwłaszcza gospodarstw rolnych z terenów Polski południowo-wschodniej. ${ }^{18}$

Kolejną pozycję co do wielkości środków finansowych przeznaczonych na wspieranie działań/poddziałań PROW 2014-2020 stanowią środki na finansowanie przedsięwzięć w ramach poddziałania „Premie dla młodych rolników”. Stanowi ono kontynuację tej samej formy wsparcia, jednakże o trudniejszych do spełnie-

Funkcjom małych gospodarstw rolnych poświęcono w ostatnim czasie sporo miejsca zarówno w ekonomicznej, jak też w prawniczej literaturze. Więcej na ten temat zob.: J. Stoksik, Formy pomocy unijnej dla małych gospodarstw rolnych, „Zeszyty Prawnicze” 2015, z. 15.1, s. 206 i nast. oraz przywoływaną tam literaturę. Problematyce funkcjonowania małych gospodarstw rolnych poświęcono w ostatnim czasie kilka konferencji naukowych. Na szczególną uwagę zasługuje Konferencja naukowo-techniczna na temat „Drobne gospodarstwa rolne w rozwoju rolnictwa i obszarów wiejskich" (organizatorzy: Porozumienie Izb Rolniczych Polski Południowo-Wschodniej, Europejskie Centrum Badawcze Drobnych Gospodarstw Rolnych, Uniwersytet Przyrodniczy w Krakowie), Chotowa, 14-15 luty 2013 r. Owocem tej Konferencji był m.in. tzw. Memoriał Podkarpacki, Minister Rolnictwa i Rozwoju Wsi kierując obszerną odpowiedź adresowaną do Prof. J. Żmiji - Dyrektora Europejskiego Centrum Badawczego Drobnych Gospodarstw Rolnych - przedstawił podejmowane przez Resort prace w zakresie projektowanych zmian dotyczacych wsparcia finansowego w ramach I i II filara WPR; odpowiedź ta jest dostępna na stronach internetowych Ministerstwa Rolnictwa i Rozwoju Wsi, www.min.rol.pl. Zakres wsparcia przewidziany dla małych gospodarstw rolnych w PROW 2014-2020 uzasadnia pogląd, że wnioski z tych konferencji zostały w dużym stopniu uwzględnione. 
nia kryteriach dostępu, realizowanej już w ramach PROW 2007-2013. W bieżącej perspektywie finansowej z kwoty 717997734 euro będzie finansowane wsparcie w formie premii dla młodych rolników, także w wysokości 100 tys. zł. Wsparcie to ma stanowić pomoc związaną z rozpoczynaniem prowadzenia gospodarstwa rolnego przez młodego rolnika, który nie ukończył 40. roku życia, posiada odpowiednie kwalifikacje rolnicze i po raz pierwszy rozpoczyna prowadzenie gospodarstwa rolnego.

Analizując dalej kryteria dostępu do tej formy wsparcia należy zwrócić uwagę, że pomoc może być udzielona w przypadku, gdy gospodarstwo legitymuje się wielkością ekonomiczną nie mniejszą niż 13 tys. euro i nie większą niż 150 tys. euro. Oznacza to, że pomoc ta ma zapoczątkowywać wsparcie dla gospodarstw raczej rozwojowych w dalszej perspektywie czasowej. Za takim docelowym charakterem gospodarstwa przemawiają inne jeszcze, narzucone do spełnienia wymogi, takie jak: określone wykształcenie, czy wymagana powierzchnia użytków rolnych, która ma być równa co najmniej średniej krajowej, a w przypadku gospodarstw położonych w województwie o średniej, niższej niż krajowa, równa co najmniej średniej wojewódzkiej, jednakże nie większa niż 300 ha.

Uzyskaniu określonych celów mają też służyć przyjęte w Programie kryteria wyboru projektów przyjętych do wsparcia. Mogą one uwzględniać w szczególności: wielkość gospodarstwa, kwalifikacje zawodowe młodego rolnika, rodzaj planowanej produkcji, kompleksowość biznesplanu, przetwarzanie produktów rolnych wytwarzanych w gospodarstwie, wpływ na realizację celów przekrojowych, różnicę wieku pomiędzy przekazującym gospodarstwo a młodym rolnikiem, udział w zorganizowanych formach współpracy producentów rolnych, przejmowanie gospodarstwa w całości lub tworzenie gospodarstwa z mniejszych gospodarstw.

Na pozytywną ocenę zasługuje również brak określenia kosztów kwalifikowalnych przedsięwzięcia, co powinno ułatwiać bardziej elastyczny wybór rodzaju przedsięwzięcia inwestycyjnego, które, jeśli zważyć na wysokość wsparcia, nie będą należały do dużych, chyba że będą stanowiły uzupełnienie środków wypracowanych $w$ gospodarstwie przed jego przejęciem. Zaznaczyć też należy, że uzyskanie tej formy wsparcia nie wyklucza możliwości uzyskania w przyszłości wsparcia innego rodzaju, np. w ramach poddziałania „Modernizacja gospodarstw rolnych”.

W chwili składania niniejszego artykułu do Wydawnictwa trwał już od 20 sierpnia nabór wniosków o wsparcie w ramach analizowanego poddziałania. Niestety zainteresowanie tą formą wsparcia nie było duże, dlatego pierwszy termin składania wniosków wydłużono do 16 września. To małe zainteresowanie, stosownie do informacji medialnych, ${ }^{19}$ tłumaczyć można zbyt wygórowanymi obecnie kryte- 
riami dostępu do tej formy wsparcia. Dotyczy to zwłaszcza możliwości dopełnienia wymogu 10-procentowego wzrostu wartości ekonomicznej gospodarstwa po zrealizowaniu biznesplanu, a także wymogami środowiskowymi, koniecznymi do spełnienia w przypadku płatności bezpośrednich. ${ }^{20}$ Równolegle ujawniły się również inne problemy w ramach wdrażanej formy wsparcia. Otóż w odniesieniu do wnioskodawców, którzy złożyli wnioski o płatności bezpośrednie za 2015 r., stosownie do kryteriów dostępu do tej formy wsparcia, przyjmuje się, że rozpoczęli oni kierowanie gospodarstwem, a to skutkowałoby pozbawieniem możliwości uzyskania premii przewidzianej $\mathrm{w}$ analizowanym tutaj poddziałaniu. $\mathrm{Z}$ tego głównie powodu rozpoczęte zostały prace legislacyjne nad zmianą rozporządzenia Ministra Rolnictwa i Rozwoju Wsi w sprawie pomocy dla młodych rolników. ${ }^{21}$ Zaznaczyć tu jednak należy, że sygnalizowana zmiana możliwa będzie pod warunkiem pozytywnych uzgodnień z KE. ${ }^{22}$

Ważne znaczenie w procesie rozwoju gospodarstw rolnych powinno mieć działanie „Przywracanie potencjału produkcji rolnej zniszczonego w wyniku klęsk żywiołowych i katastrof oraz wprowadzanie odpowiednich środków zapobiegawczych" (art 18 rozporządzenia EFRROW). Jego uruchomienie jest odpowiedzią wynikającą z coraz częstszej konieczności zabezpieczania gospodarstw rolnych przed skutkami występowania ekstremalnych zjawisk pogodowych (np. suszy) z jednej strony, z drugiej natomiast, z potrzeby wsparcia odbudowy zniszczonego w wyniku klęsk żywiołowych, niekorzystnych zjawisk klimatycznych lub katastrof, potencjału produkcyjnego. Przewidziane wsparcie ma formę refundacji części kosztów kwalifikowalnych operacji. Zakłada się, że zarówno inwestycje odtwarzające potencjał zniszczonej produkcji rolnej, jak też zapobiegające zniszczeniu potencjału produkcji rolnej, wpłyną pośrednio na poprawę rentowności gospodarstw rolnych oraz na ich konkurencyjność w sytuacji wystąpienia takich klęsk żywiołowych lub zjawisk przyrodniczych. Obywa te poddziałania realizować będą cel szczegółowy określony w pkt $3 b$ art. 5 rozporządzenia EFRROW: „wspieranie zapobieganiu ryzyka i zarządzanie ryzykiem w gospodarstwach", a także cele przekrojowe dotyczące środowiska i klimatu.

Pomoc $w$ ramach pierwszego poddziałania przewidziana jest na materialne i niematerialne inwestycje odtwarzające potencjał produkcji roślinnej lub zwierzęcej, $\mathrm{z}$ wyłączeniem nieubezpieczonych budynków i budowli objętych ubezpieczeniem nowione do uzyskania płatności za zazielenienie, które narzucając praktyki przynoszące korzyści, głównie dla środowiska nie prowadzą do poprawy kondycji ekonomicznej gospodarstwa.

21 Chodzi o rozporządzenie z dnia 13 lipca 2015 r. w sprawie szczegółowych warunków i trybu przyznawania wypłaty oraz zwrotu pomocy finansowej na operacje typu „Premie dla młodych rolników” w ramach poddziałania „Pomoc w rozpoczynaniu działalności gospodarczej na rzecz młodych rolników objętą Programem Rozwoju Obszarów Wiejskich na lata 2014-2020", Dz.U. z 2015 r. poz. 982. 
obowiązkowym. Wszystkie objęte $\mathrm{w}$ ramach tego poddziałania inwestycje muszą być związane z działalnością rolniczą i mogą dotyczyć przygotowania do sprzedaży produktów wytwarzanych w gospodarstwie rolnym. Pomoc w ramach drugiego poddziałania udzielana jest na zaopatrzenie w sprzęt do utrzymania urządzeń wodnych służących zabezpieczeniu gospodarstw rolnych przed zalaniem, podtopieniem lub nadmiernym zawilgoceniem spowodowanym przez powódź lub deszcz nawalny. Beneficjentami tego poddziałania mogą być spółki wodne, w których członkami są w przewadze rolnicy, a także związki tych spółek. Zaznaczyć też należy, że kwoty wsparcia obejmują aż $80 \%$ kosztów kwalifikowalnych i nie mogą przekroczyć 500 tys. zł.

Analizując powyższe, nowe formy wsparcia, należy je ocenić jako niezwykle potrzebne. Tegoroczna susza uzasadnia pilną potrzebę rozważenia wsparcia na rzecz budowy urządzeń łagodzących jej skutki. Mogą to być urządzenia wodne gromadzące zapasy wody, których bardzo brakuje. ${ }^{23}$

Kolejnym ważnym działaniem na rzecz rozwoju gospodarstw rolnych oraz wzmacniania ich konkurencyjności jest działanie ,Tworzenie grup i organizacji producentów". Podstawę prawną dla tego działania stanowi art. 27 rozporządzenia EFRROW. Tworzenie grup i organizacji producentów rolnych wynika z rosnących wymogów odbiorców surowców rolnych i ma szczególne znaczenie w związku z rozdrobnieniem agrarnym. Dla producentów rolnych, zwłaszcza tych drobnych, udział w grupie producentów rolnych oznacza stabilizację zbytu produktów, a przez to zwiększenie opłacalności produkcji. Działania grupowe wzmacniają też pozycję producentów rolnych w łańcuchu żywnościowym i sprzyjają zwiększaniu ich udziału w wartości dodanej. Są też korzystne dla odbiorców surowca, gdyż zapewniają regularność dostaw, dostosowanie ich wielkości do potrzeb oraz są gwarantem lepszej jakości surowca.

Grupy i organizacje producentów realizują ważny cel szczegółowy wsparcia; wyartykułowany w pkt 3a art. 5 rozporządzenia EFRROW: ,poprawa konkurencyjności producentów rolnych poprzez lepsze ich zintegrowanie z łańcuchem rolnospożywczym poprzez systemy jakości, dodawanie wartości do produktów rolnych, promocję na rynkach lokalnych i krótkie cykle dostaw przez grupy i organizacje producentów oraz organizacje między - branżowe".

Ważną funkcją grup i organizacji producentów rolnych jest też wprowadzanie nowych rozwiązań w zakresie organizacji produkcji i marketingu, a także technologii produkcji. Prowadzi to do zwiększenia innowacyjności sektora rolnego. Nadto warte w rządowym dokumencie „Strategia gospodarki wodnej” przyjętym przez Radę Ministrów w dniu 13 września 2005 r., w którym przyjmuje się słusznie (s. 12 i nast.), że w Polsce nie istnieje system zabezpieczeń przed suszą; dokument ten dostępny jest na stronach internetowych Ministerstwa Środowiska, www.mos.gov.pl 
planowanie optymalnej, zgodnej z wymogami ochrony środowiska, produkcji rolnej w grupie, przy dbałości o jej jakość, następnie sprzedaż i organizowanie całego zaplecza produkcyjnego będą bezpośrednio pozytywnie wpływać na środowisko naturalne. ${ }^{24}$

Formę wsparcia stanowi procentowy ryczałt od wartości przychodów netto grupy lub organizacji producentów ze sprzedaży produktów wytworzonych w gospodarstwach rolnych jej członków w poszczególnych latach i sprzedanych odbiorcom niebędącym członkami grupy lub organizacji. Ryczałt ten, do 100 tys. euro, wypłacany będzie w każdym roku 5-letniego okresu pomocy, w odniesieniu do wielkości produkcji sprzedanej: $10 \%$ za pierwszy rok, $8 \%$ za drugi rok, $6 \%$ za trzeci rok, $5 \%$ za czwarty rok i $4 \%$ za piąty rok.

Analizując to poddziałanie warto też odnotować przewidziane preferencje w przyznawaniu pomocy dla grup i organizacji producentów. Tak więc preferowane będą grupy:

- zorganizowane w formie spółdzielni;

- zrzeszające producentów w następujących kategoriach: produkty wysokiej jakości objęte art. 16 EFRROW (dotyczącym wsparcia systemów jakości produktów rolnych i środków spożywczych), w szczególności rolnictwa ekologicznego, świnie żywe, prosięta, warchlaki, mięso wieprzowe, bydło żywe, owce lub kozy żywe, miód naturalny i produkty pszczele, rośliny w plonie głównym, z przeznaczeniem na cele energetyczne lub do wykorzystania technicznego szyszki chmielowe;

- zrzeszające jak największą liczbę członków w danej kategorii;

- zrzeszające producentów w gospodarstwach, których produkcja objęta została dobrowolnym ubezpieczeniem.

Aby uniknąć ryzyka związanego z wdrażaniem działań wprowadza się warunek, że o wsparcie może ubiegać się grupa producentów złożona tylko z osób fizycznych, co ma umożliwić dokładne zweryfikowanie przynależności danego producenta. Program zalecił również potrzebę doprecyzowania wymogów wsparcia na etapie jego wdrażania.

W ramach działania „Rozwój gospodarstw i działalności gospodarczej” skierowanym na poprawę konkurencyjności gospodarstwa poprzez powiększenie jego powierzchni jest poddziałanie „Płatność dla rolników przekazujących małe gospo-

24 Pozycja i znaczenie grup producentów rolnych w UE są zróżnicowane. W Polsce grupy producentów wspierane różnymi formami pomocy finansowej zaczynają powoli odgrywać coraz to większe znaczenie w produkcji i dystrybucji żywności; więcej o funkcjach grup producentów w literaturze prawniczej zob. zwłaszcza: B. Jeżyńska, A. Oleszko, Prawo rolne i żywnościowe, Kraków 2003, s. 203 i nast.; z literatury ekonomicznej ciekawą pozycję w tym zakresie stanowi praca W. Michny, Organizacje wiejskie i rolnicze oraz ich rola w rozwoju obywatelskiej demokracji i krajowej demokracji, Warszawa 2010. 
darstwa". Przewidziane tutaj wsparcie przyznawane jest w postaci płatności jednorazowej, odpowiadającej $120 \%$ rocznej płatności, do otrzymania której beneficjent kwalifikuje się w ramach systemu wsparcia dla małych gospodarstw, ustanowionym zgodnie z tytułem piątym rozporządzenia w sprawie płatności bezpośrednich.

Beneficjentem wsparcia jest rolnik będący osobą fizyczną, który kwalifikuje się do systemu dla małych gospodarstw, ustanowionego w rozporządzeniu w sprawie płatności bezpośrednich i trwale przekazał w drodze sprzedaży lub darowizny swoje gospodarstwo rolne innemu rolnikowi. Gospodarstwo przejmujące grunty od beneficjenta musi posiadać lub osiągnąć po przejęciu gruntów od beneficjenta co najmniej wielkość odpowiadającą średniej wielkości gospodarstwa w Polsce lub średniej wielkości w województwie, w którym średnia powierzchnia gospodarstwa jest większa od średniej krajowej.

Warto jeszcze wskazać na przewidziane preferencje w ramach tego poddziałania. Tak więc preferuje się przekazywanie gospodarstw większych, następnie preferencje obejmą gospodarstwa mniejsze przejmujące grunty. Będą wreszcie przewidziane preferencje dla przekazywania gruntów młodym rolnikom.

W ramach działania „Inwestycje w środki trwałe” pozostają też dwa poddziałania; ,Inwestycje w gospodarstwach położonych na obszarach Natura 2000” oraz „Inwestycje w gospodarstwach położonych na obszarach OSN”. Są one skierowane w głównej mierze na poprawę konkurencyjności gospodarstw rolnych położonych na tych terenach (art. 17 rozporządzenia EFRROW).

Na obszarach Natura 2000 na gospodarstwa rolne nakłada się wiele powinności związanych z obowiązkiem realizacji zadań ochronnych, przewidzianych dla danego obszaru. Ta ochrona odnosi się zwłaszcza do gospodarowania na trwałych użytkach zielonych. Dlatego też w PROW 2014-2020 przewidziano instrument wspierania inwestycji związanych z rolniczym wykorzystaniem łąk i pastwisk oraz produkcją zwierzęcą, prowadzonymi zgodnie z wymogami ochrony środowiska. Ze względu na możliwość stosowania nowych rozwiązań technologicznych w zakresie ochrony środowiska i planowany typ operacji, działanie to, ma też wymiar proinnowacyjny oraz realizuje cele przekrojowe w zakresie środowiska i klimatu.

Wsparcie w ramach przewidzianego dla tych obszarów poddziałania ma formę refundacji części kosztów kwalifikowalnych operacji, realizowanej przez beneficjenta-rolnika w wysokości nie przekraczającej:

- 200 tys. zł w przypadku gdy operacja obejmuje budowę lub modernizację budynków inwentarskich,

- 500 tys. zł w przypadku gdy operacja obejmuje budowę, modernizację budynków inwentarskich lub adaptację na budynki inwentarskie innych, już istniejących w gospodarstwie, budynków. 
Wsparciem można objąć 60\% kosztów kwalifikowalnych przedsięwzięcia w przypadku młodych rolników, a w przypadku pozostałych operacji 50\% kosztów kwalifikowalnych.

Warto jeszcze wskazać na wyartykułowane w Programie preferencje przewidziane dla tego poddziałania. Tak więc dotyczyć one będą gospodarstw posiadających dużą powierzchnię trwałych użytków zielonych, następnie operacje obejmujące inwestycje ściśle związane z wymogami planu ochrony obszaru Natura 2000 oraz operacje realizowane przez młodych rolników.

Poddziałanie „Inwestycje w gospodarstwach położonych na obszarach OSN” dotyczy obszarów szczególnie narażonych na zanieczyszczenia azotanami ze źródeł rolniczych. Dlatego też gospodarstwa położone na tych terenach powinny posiadać urządzenia do gromadzenia i przechowywania nawozów naturalnych przez okres co najmniej 6 miesięcy, aby można było je następnie wykorzystać racjonalnie w sposób minimalizujący zanieczyszczenia wód gruntowych. Wsparcie to ma ułatwiać dostosowywanie się gospodarstw do nowych wymogów, wynikających głównie z ustawy $\mathrm{z}$ dnia 10 lipca $2007 \mathrm{r}$. o nawozach i nawożeniu. ${ }^{25}$

Pomoc ma formę refundacji części kosztów kwalifikowalnych operacji, realizowanej przez beneficjenta-rolnika i obejmuje $60 \%$ tych kosztów w przypadku operacji realizowanej przez młodego rolnika i 50\% tychże kosztów w pozostałych przypadkach. Maksymalna wielkość pomocy dla jednego beneficjenta i jednego gospodarstwa nie może jednak przekroczyć 50 tys. zł.

Przeanalizowane wyżej działania/poddziałania/operacje PROW 2014-2020 zaliczyć można do tej grupy, które bezpośrednio skierowane są na rozwój gospodarstw rolnych w Polsce. Pośredni wpływ na ten rozwój mają również inne działania Programu, które można ująć w następujące grupy: wzmacnianie przedsiębiorczości, rozwój terytorialny, transfer wiedzy i innowacji, wsparcie jakości produkcji oraz ochrona ekosystemów i efektywne gospodarowanie zasobami naturalnymi.

Poza działaniami PROW 2014-2020 wpływ na rozwój gospodarstw rolnych będą miały również mechanizmy polityki rynkowo-dochodowej, finansowane ze środków Europejskiego Funduszu Rolnego Gwarancji (EFRG), głównie dopłaty bezpośrednie. Nie bez znaczenia na rozwój gospodarstw rolnych, jako najważniejszego elementu obszarów wiejskich, będzie miało wsparcie tych terenów ze środków Funduszu Spójności (FS).

Wreszcie rozwój gospodarstw rolnych wspierany będzie ze środków wyłącznie krajowych, głównie w formie dopłat do oprocentowania kredytów udzielanych 
przez banki na sfinansowanie przedsięwzięć inwestycyjnych w gospodarstwach rolnych. $^{26}$

Zmierzając do próby ogólnej oceny działań/poddziałań/operacji PROW 20142020 należy najpierw zastrzec, że na obecnym, początkowym etapie ich wdrażania może mieć ona jedynie charakter wstępny. W kolejności należy też zauważyć, że analizowany Program, nad którym prace trwały od 2012 roku, na każdym etapie jego tworzenia podlegał szerokim konsultacjom społecznym, w tym także wśród jego beneficjentów oraz podmiotów zajmujących się profesjonalnie wdrażaną pomocą unijną. Do tej ostatniej grupy zaliczyć należy prace różnych instytucji naukowych. Na szczególną uwagę zasługują tutaj, przywoływane w niniejszej pracy, raporty naukowe dotyczące strategii i polityk sektora rolnego na świecie i w UE oraz nakreślenie kierunków ich rozwoju i wynikających z tego implikacji dla gospodarki żywnościowej w Polsce. Odnosząc się do treści prezentowanych w tym zakresie analiz naukowych, należy zwrócić uwagę na dużą zgodność formułowanych w nich ustaleń i wniosków. Przykładowo wszystkie ośrodki badawcze zgodnie wskazują na potrzebę istotnych zmian w polityce rozwoju, zgodnie twierdząc, że powinna ona bardziej zdecydowanie stawiać na innowacyjność w zakresie wykorzystywania potencjału sfery publicznej, prywatnej oraz obywatelskiej. Z powyższym stanowiskiem należy się bezsprzecznie zgodzić tym bardziej, że taki sam wniosek został wyprowadzony z analizy SWOT, przeprowadzonej na użytek prac projektowych nad PROW 2014-2020.

Projektując zakres wsparcia, w każdym programie pomocowym trzeba mieć na uwadze to, że jego zakres zawsze bywa determinowany wielkością pozostających do dyspozycji środków finansowych. Choć ich wielkość, jaka przypadła Polsce na obecną perspektywę finansową UE należy do najwyższych we Wspólnocie, to z całą pewnością środki te nie wystarczą, aby zaspokoić wszystkie potrzeby rozwoju naszego rolnictwa oraz terenów wiejskich. Wydaje się jednakże, że można wyrazić pogląd, iż analizowany tutaj PROW 2014-2020 jest dokumentem kompromisowym, najbardziej optymalnym i w dużym zakresie wychodzącym naprzeciw oczekiwaniom dużej części zainteresowanych nim podmiotów.

Najważniejszym priorytetem nowego PROW 2014-2020 jest poprawa konkurencyjności sektora rolnego, z uwzględnieniem celów środowiskowych. Nowy Program wspierać będzie także rozwój przetwórstwa rolno-spożywczego, niezwykle ważnego czynnika rozwoju gospodarstw rolnych, produkujących surowiec do dalszego przetwarzania. Priorytet ten wynika zarówno ze zidentyfikowanych potrzeb gwarantujących rozwój naszego sektora rolnego i obszarów wiejskich, jak też 
z przywoływanych wyżej przepisów prawa unijnego, realizujących politykę rozwoju obszarów wiejskich UE. Może jednak zastanawiać duża kwota środków przewidzianych w planie finansowym Programu na wspieranie działań pro-środowiskowych (ponad 30\%), w sytuacji gdy Polska, a zwłaszcza jej tereny rolnicze, zaliczane są do najmniej skażonych w UE. Tak wysoki nakład środków finansowych wynika jednakże z woli prawodawcy unijnego, nakazującej zabezpieczenie tego wymogu w programach pomocowych rozwoju rolnictwa i obszarów wiejskich. Dbałości o środowisko rolnicze, także tej narzuconej „,z góry”, nie można oceniać negatywnie, jeśli zważyć, że na sukces dobrej jakościowo polskiej żywności, mierzony ciągłym wzrostem jej eksportu, składa się również to, że jest ona produkowana w warunkach mało jeszcze skażonego intensywną działalnością rolniczą środowiska. Przewaga małych gospodarstw rolnych w Polsce stwarza dodatkową szansę na rozwój tych gospodarstw, w których może być wytwarzany nie tylko dobry jakościowo surowiec, ale również wyżej przetworzona ekologiczna i tradycyjna żywność. Z tej też przyczyny działania wspierające rozwój małych gospodarstw rolnych wypada ocenić również pozytywnie.

Podstawowym jednak działaniem skierowanym na rozwój konkurencyjnego rolnictwa pozostaje nieprzerwanie „Modernizacja gospodarstw rolnych”. Jest to kierunek słuszny, jeśli zważyć, że to duże gospodarstwa rolne są najlepszym gwarantem rozwoju naszego rolnictwa, które stale musi wytrzymywać wzrastającą konkurencję, ze strony silnych, dużych gospodarstw „starej Unii”. Pozytywnie należy też ocenić wsparcie objęte tym poddziałaniem, z racji skierowania go na trzy najbardziej zagrożone obszary działalności rolniczej, tj. chów trzody chlewnej, chów bydła mlecznego oraz rzeźnego. $Z$ różnych analiz wynika bowiem, że w tych trzech obszarach jesteśmy najmniej konkurencyjni.

Globalny, światowy rynek żywnościowy, w którego orbitę wpisujemy się coraz mocniej, wymuszał będzie jednocześnie potrzebę przygotowywania się do przyjmowania coraz większych wyzwań konkurencyjnych. Mając to na uwadze słusznie przyjęto w Programie, że ogólne zapotrzebowanie na żywność realizować mogą nie tylko duże gospodarstwa rolne, ale również te małe, które przez wiele lat będą nadal pełnić wielorakie funkcje produkcyjne i społeczne. Wsparcie tych ostatnich będzie jednak możliwe pod warunkiem, że w jego wyniku nastąpi pożądany wzrost ich wartości ekonomicznej. Można też zakładać, że małe, nieproduktywne gospodarstwa rolne będą sukcesywnie, w naturalny sposób, odchodzić od działalności rolniczej i zasilać swymi gruntami większe, rozwojowe gospodarstwa. W tym jednak zakresie, brak jest wyraźnej wizji co do stymulowania ich przyszłości.

Popierana w ramach działalności rolniczej innowacyjność może być najskuteczniej realizowana głównie przez ludzi młodych. Dlatego też pozytywnie należy odnotować zwiększenie zakresu wsparcia dla młodych rolników w obecnym Progra- 
mie, wyrażającego się poprzez większe preferencje finansowe i łagodniejsze kryteria dostępu do różnych form wsparcia.

Polskie organizacje rolnicze ocenia się jako słabe i mało skuteczne. Słusznie zatem, wzorem form wsparcia dla młodych rolników, przyjęto w Programie podobne preferencje dla różnych form zespołowego współdziałania, zarówno w sferze produkcji, jak również w zakresie organizacji i zdobywania rynków zbytu.

Ekonomicznie uzasadnionym rozwiązaniem nowego Programu są także działania stymulujące tworzenie nowych miejsc pracy na terenach wiejskich. Pozwoli to nie tylko na łagodzenie problemów bezrobocia na terenach wiejskich, a także na łagodniejsze odchodzenie od działalności rolniczej i likwidację mało efektywnych gospodarstw rolnych, które powinny być przejmowane przez gospodarstwa silniejsze.

O tym, czy zaprojektowane w PROW 2014-2020 formy wsparcia zapewnią dalszy, skuteczny rozwój rolnictwa oraz terenów wiejskich, decydować będą również rozwiązania szczegółowe, jakie będą przyjmowane w kolejnych rozporządzeniach Ministra Rolnictwa i Rozwoju Wsi, w związku z uruchamianiem kolejnych działań Programu.

O powodzeniu obecnego Programu zadecydują wreszcie inne formy wsparcia, przewidziane poza nim. Wskazać tu należy przede wszystkim na system dopłat bezpośrednich, które pozostają nadal podstawowym instrumentem WPR w zakresie poprawy dochodów unijnego producenta rolnego. Zreformowany obecnie system płatności bezpośrednich wyraźnie preferuje gospodarstwa rozwojowe i działania rolnośrodowiskowe. W jednym i drugim przypadku funkcją dopłat jest rekompensowanie dochodów producenta rolnego, których nie był w stanie osiągnąć z powodu niekorzystnej dla niego sytuacji na rynku żywnościowym, czy ograniczeń w działalności rolniczej wynikających z wymogów środowiskowych.

Za każdym z zaprogramowanych działań kryją się określone cele. Aby je osiągnąć, obok wsparcia finansowego, istnieje również potrzeba dopracowania się przyjaznej polityki podatkowej wobec beneficjentów wielu działań, pozbawionej zwłaszcza cechy fiskalizmu. Może to mieć miejsce w przypadku przedsięwzięć o charakterze nierolniczym, na przykład w zakresie prowadzonej działalności przetwórczej, podejmowanej w gospodarstwach rolnych. Powodzenie różnych przedsięwzięć zależeć też będzie od rozsądnie kształtowanych treści norm prawnych, takich przykładowo, jak: wymogi sanitarne, wymogi w zakresie sprawozdawczości, itd. Wydaje się, że stosowanie takich samym wymogów w odniesieniu do wszystkich producentów żywności nie znajduje swojego uzasadnienia i może prowadzić, wraz $\mathrm{z}$ upadkiem przedsięwzięcia, do zniweczenia bezpowrotnie celu, w którego realizację zaangażowane zostały określone środki publiczne. 
FORMS OF SUPPORT FOR THE DEVELOPMENT OF FARMS IN THE RURAL DEVELOPMENT PROGRAMME FOR 2014-2020

Key words: Common Agricultural Policy, competitiveness of farms, economic SWOT analysis, criteria for the access, Rural Development Programme.

The new financial perspective covering the period 2014-2020 has brought many changes. The main priority of the new rural development policy is to improve the competitiveness of farms, having regard to environmental objectives. Rural Development Programme for years 2014-2020 will encourage further restructuring and modernization of farms and development of agri-food processing as well as strengthening their competitiveness in EU and global food market. Development of farms will also be supported by seven sub-measures of current Rural Development Programme. The most important needs of rural areas have been established using the popular SWOT analysis. Implementation of these needs is to induce specific criteria for the access to the various forms of financial assistance as provided for in the Program. Author of this article takes the view that they have been aptly chosen and should result in effective implementation of the objectives of the current Rural Development Programme.

\section{Bibliografia:}

R. Grochowska (red.), Kierunki rozwoju rolnictwa i polityk rolnych - wyzwania przyszłości (Synteza), Warszawa 2014.

B. Jeżyńska, A. Oleszko, Prawo rolne i żywnościowe, Kraków 2003.

W. Józwiak (red.), Efektywność, koszty produkcji i konkurencyjność polskich gospodarstw rolnych w ramach globalizacji gospodarki światowej, Warszawa 2014.

A. Jurcewicz (red.), Prawo i polityka rolna Unii Europejskiej, Warszawa 2010.

Materiały z Konferencji naukowo-technicznej nt. Drobne gospodarstwa rolne w rozwoju rolnictwa i obszarów wiejskich, Chotowa 14-15 luty 2013.

W. Michna, Organizacje wiejskie i rolnicze oraz ich rola w rozwoju obywatelskiej demokracji i krajowej demokracji, Warszawa 2010.

J. Stoksik, Formy pomocy unijnej dla małych gospodarstw rolnych, „Zeszyty Prawnicze” 2015, z. 15.1 . 